\title{
Viral antibody studies in pancreatic disease
}

\author{
P. CAPNER, R. LENDRUM, D. J. JEFFRIES, AND GEOFFREY WALKER
}

From the Departments of Virology and Gastroenterology, St. Mary's Hospital, London

SUMMARY Viral studies were performed on sera from 54 patients with recent acute pancreatitis, 10 with recurrent acute pancreatitis, seven with chronic pancreatitis, and 10 with pancreatic carcinoma, and on sera from 81 age- and sex-matched controls. In 29 of the acute pancreatitis patients from whom paired sera were obtained no convincing evidence of recent viral infection was found. A higher incidence of raised antibody titres against Coxsackie $B_{3}$ and $B_{4}$ was observed in the group of acute pancreatitis patients compared with their controls. The possible significance of these observations and their relationship to the aetiology of the pancreatitis and to other immunological findings are discussed.

Accepted factors predisposing to the development of acute pancreatitis include biliary tract disease, alcoholism, trauma or recent abdominal surgery, pancreatic neoplasia, metabolic disorders resulting in hypercalcaemia and hyperlipidaemia, mumps virus infection, corticosteroids and possibly other drugs, while rarely there may be a genetic component (Gambill, 1973). In approximately one-third of cases none of these factors can be incriminated (Trapnell and Duncan, 1975). However, acute pancreatitis may occur occasionally in patients with evidence of other viral infections-for example, congenital rubella (Bunnell and Monif, 1972) and infectious mononucleosis (Myhre and Nesbitt, 1949; Wislocki, 1966; Everett et al., 1969). There may also be an association between infective hepatitis and pancreatitis, reflecting a possible common viral cause (Lisney, 1943; Joske, 1955; Achord, 1968; Gillespie, 1973; Ham and Fitzpatrick, 1973). Pancreatitis has been reported in Coxsackie B infection (Kibrick and Benirschke, 1958; Fechner et al., 1963; Murphy and Simmul, 1964; Ursing, 1973), and in one epidemiological study serum amylase levels were elevated in $31 \%$ of patients during an outbreak of Coxsackie $B_{5}$ infection (Nakao et al., 1964). Pancreatic damage can be produced in animals by several viruses, including infectious pancreatic necrosis virus in trout (Wood et al., 1955), and Coxsackie B (Pappenheimer et al., 1951; Minkowitz and Berkovich, 1970; Burch et al., 1971; Harrison et al., 1972; Tsui et al., 1972; Ross et al., 1974), encephalomyocarditis (Craighead, 1965; Burch et al., 1974), foot and mouth disease (Platt,

Received for publication 18 September 1975.
1956), and mouse hepatitis (Hirano and Ruebner, 1968) viruses, in mice.

Evidence that virus infection is commonly responsible for human pancreatitis is lacking and in a recent serological study, significantly elevated antibody titres were not encountered (Leinikki et al., 1973). However, significantly raised antibody titres to Mycoplasma pneumoniae occurred in onethird of patients and pancreatitis has been reported as a complication of Mycoplasma pneumoniae infection (Mårdh and Ursing, 1974).

We report here further virological studies on a group of patients with pancreatic disease, whose sera have also been tested for the presence of autoantibodies reacting with pancreatic acinar cells (Lendrum and Walker, 1975).

\section{Methods}

SUBJECTS WITH PANCREATIC DISEASE

The sera examined in this study had been collected initially as part of another investigation (Lendrum and Walker, 1975) and stored at $-20^{\circ} \mathrm{C}$. Sera were available from 54 patients whose clinical picture and serum amylase levels were compatible with acute pancreatitis (27 males, 27 females; ages 19 to 90 years). Paired sera were available from 29 of these patients. In these subjects, serum was taken within seven days of the onset of abdominal pain, and there was an interval of six or more days between acute and convalescent sera. In the remaining 25 patients, single sera only were examined. These had been obtained at varying intervals after the onset of illness (within one week-12 patients; within one month-five patients; between one and four 


\begin{tabular}{lcc}
\hline $\begin{array}{l}\text { Associated } \\
\text { Conditions }\end{array}$ & $\begin{array}{l}\text { Total } \\
\text { Numbers }\end{array}$ & $\begin{array}{l}\text { Patients with } \\
\text { paired serum } \\
\text { samples available }\end{array}$ \\
\hline Alcohol abuse & 12 & 10 \\
Biliary tract disease & 13 & 4 \\
Recent abdominal surgery & 2 & 2 \\
Carcinoma of pancreas & 1 & -13 \\
None & $26^{*}$ & 13 \\
\hline
\end{tabular}

Table 1 Associated clinical conditions in 54 patients with acute pancreatitis

* Two of these patients were receiving oral contraceptive drugs, and two others were receiving frusemide.

months-eight patients). Associated clinical conditions in the pancreatitis patients are shown in Table 1. No causative factors for the pancreatitis were evident in 26 patients, although two of these were receiving oral contraceptive drugs and two others were being treated with frusemide. Both of these drugs have been suggested as possible rare causes of the disease (Bank and Marks, 1970; Davidoff et al., 1973; Jones and Oelbaum, 1975).

Single serum samples were also examined from 10 patients with relapsing acute pancreatitis (one to five previous attacks), within five weeks of the most recent episode. Single sera from seven patients with chronic pancreatitis diagnosed radiologically or on biopsy, and from 10 patients with pancreatic carcinoma confirmed at laparotomy or at necropsy, were also studied.

\section{CONTROLS}

Sera from the patients with pancreatic disease were matched with stored sera which previously had been investigated for possible virus infections. None of these control sera was from patients with known pancreatic disease. The sera were matched for age and sex, and the date of their collection was matched to within one month to counteract any bias due to seasonal incidence of viral infections. Sera fulfilling these criteria were chosen without regard to previous virological findings. All sera, both from patients and from controls, were collected from patients living in West London.

\section{VIROLOGICAL METHODS}

Antibody testing by complement fixation (Bradstreet and Taylor, 1962) was performed using the following antigens: measles, mumps soluble and viral antigens, influenza $A$ and $B$, parainfluenza 1 and 3 , respiratory syncytial virus, adenovirus, varicellazoster, cytomegalovirus, herpes simplex, Rickettsia burneti, psittacosis/LGV, and Mycoplasma pneumoniae. The sera were screened initially at a dilution of $1: 20$, and any which were positive were titrated in serial doubling dilutions. Rubella virus antibodies were determined by the haemagglutination-inhibition test (Stewart et al., 1967) using sera which had been pre-treated with heparin and manganese chloride (Feldman, 1968). Antibodies to Coxsackie B virus types 1-6 were determined by a conventional neutralization test in Vero cells, using 100 TCID 50 virus challenge. The serum/virus mixtures were incubated at $37^{\circ} \mathrm{C}$ for 90 minutes before innoculation, and results read after three days. All sera were tested for the presence of Hepatitis $B$ antigen $\left(\mathrm{HB}_{\mathrm{s}} \mathrm{Ag}\right)$ by the turkey cell haemagglutination test (Wellcome Reagents, Ltd), and for evidence of infectious mononucleosis by a slide absorption test (Mercia Diagnostics, Ltd).

\section{Results}

Among the 29 patients with acute pancreatitis in whom paired sera were tested, two showed four-fold rises in antibody titres against herpes simplex; one of these two also showed a four-fold rise against varicella zoster. No other significant increases in antibody titres were observed. One of the 54 patients with acute pancreatitis had a high antibody titre against the psittacosis/LGV group antigen (1:1280) on a single serum specimen; there was no clinical evidence of infection with these organisms. No other patient had antibody levels suggestive of recent infection with any of the agents tested.

Sera from the 54 patients with acute pancreatitis were compared with their controls. The convalescent serum from the 29 patients with paired sera was used for this comparison. There was a significantly greater incidence of antibodies to Coxsackie $B_{3}$ and $B_{4}$ viruses among the patients with acute pancreatitis $\left(\mathrm{B}_{3}, 59 \% ; \mathrm{B}_{4}, 59 \%\right)$ compared with

\begin{tabular}{|c|c|c|c|c|}
\hline \multirow[t]{2}{*}{ Virus } & \multicolumn{2}{|c|}{ Acute pancreatitis } & \multicolumn{2}{|c|}{ Relapsing acute pancreatitis } \\
\hline & $\begin{array}{l}\text { Patients } \\
\text { (54) }\end{array}$ & $\begin{array}{l}\text { Controls } \\
(54)\end{array}$ & $\begin{array}{l}\text { Patients } \\
(10)\end{array}$ & $\begin{array}{l}\text { Controls } \\
\text { (10) }\end{array}$ \\
\hline Adenovirus & 8 & $20^{*}$ & 0 & 5 \\
\hline Mumps S & 3 & 4 & 0 & 0 \\
\hline Mumps V & 9 & 12 & 3 & 4 \\
\hline Rubella & 44 & 38 & 8 & 5 \\
\hline \multicolumn{5}{|l|}{ Coxsackie } \\
\hline $\mathbf{B}_{1}$ & 10 & 11 & 4 & 4 \\
\hline $\mathbf{B}_{\mathbf{2}}$ & 24 & 24 & 4 & 3 \\
\hline $\mathbf{B}_{\mathbf{3}}$ & $32 \dagger$ & 13 & 7 & 2 \\
\hline $\mathbf{B}_{4}$ & $32 \dagger$ & 18 & 5 & 4 \\
\hline $\mathbf{B}_{5}$ & 4 & 3 & 3 & $\mathbf{0}$ \\
\hline $\mathbf{B}_{6}$ & 1 & $\mathbf{0}$ & $\mathbf{0}$ & 0 \\
\hline
\end{tabular}

Table 2 Numbers of patients with pancreatitis, and of controls, who showed antibody titres $>1: 20$ against different viruses

* Significantly greater number of controls, $x^{2}=5.8$, P $<.025$ †Significantly greater number of patients; $B_{3} x^{2}=12 \cdot 3, P<\cdot 005$ B, $x^{2}=6 \cdot 3, P<\cdot 025$ 


\begin{tabular}{lccccc}
\hline Associated conditions & \multicolumn{2}{c}{ Total numbers* } & \multicolumn{5}{c}{ Antibodies to Coxsackie virus $>1: 20$} \\
\cline { 3 - 6 } & & $B_{\mathbf{3}}$ alone & $B_{4}$ alone & $B_{3}$ and $B_{4}$ & Neither \\
\hline None & $26(7)$ & $4(1)$ & $7(2)$ & $9(4)$ & 6 \\
Biliary disease & $13(3)$ & $3(1)$ & - & $6(2)$ & 4 \\
Alcohol abuse & $12(7)$ & $3(1)$ & - & $1(4)$ & $1(1)$ \\
Recent abdominal surgery & $2(0)$ & 1 & - & $1(1)$ & - \\
Carcinoma of pancreas & $1(1)$ & $11(3)$ & $11(3)$ & $21(11)$ & $11(1)$ \\
\hline Totals & $54(18)$ & &
\end{tabular}

Table 3 Numbers of acute pancreatitis patients with Coxsackie $B_{3}$ or $B_{4}$ antibody titres $>1: 20$, related to associated clinical conditions

*Figures in parentheses represent patients with autoantibodies to acinar cells, demonstrable by immunofluorescence.

controls $\left(\mathrm{B}_{3}, 24 \% ; \mathrm{B}_{4}, 33 \%\right)$ when the sera were screened at 1:20 dilution. There were no other differences in antibody levels between the two groups apart from a significantly higher incidence of antibodies to adenovirus in the control group (Table 2).

Seven of the 10 patients with relapsing acute pancreatitis had antibody titres $>1: 20$ against Coxsackie $B_{3}$, compared with only two of their controls. No differences between patients and controls were found among the smaller numbers of chronic pancreatitis or carcinoma subjects.

The raised antibody titres against Coxsackie B viruses did not correlate in any way with the presence or absence of other non-viral factors associated with the pancreatitis (Table 3). Included among the 54 acute pancreatitis patients were 18 who had been found to have serum autoantibodies reacting in indirect immunofluorescent tests with the acinar cells of normal pancreas (Lendrum and Walker, 1975) from patients of blood group O. Seventeen of these had antibody titres $>1: 20$ against Coxsackie $B_{3}$ or $B_{4}$. Twenty-six of the 36 patients without detectable acinar-cell autoantibodies had Coxsackie $\mathbf{B}_{3}$ or $\mathbf{B}_{4}$ antibodies at this level. There was no statistically significant difference in incidence of Coxsackie $B_{3}$ and $B_{4}$ antibodies between those with and without acinar-cell autoantibodies $\left(\chi^{2}=2 \cdot 4\right.$, $P>0 \cdot 1$ ).

No rises in antibody titres against Mycoplasma pneumoniae were observed in the paired sera, and titres $>1: 20$ against Mycoplasma pneumoniae were seen in only four of all those with acute pancreatitis, and in four controls. No evidence of recent mumps infection was found in acute pancreatitis patients or in any of those with other pancreatic diseases. Similarly, all patients and controls were $\mathrm{HB}_{\mathrm{s}} \mathrm{Ag}$ negative, and were negative in the infectious mononucleosis screening test.

\section{Discussion}

No evidence was found in the present study that pancreatic disease was caused by acute viral infection, although two acute pancreatitis patients in whom paired sera were studied showed small increases in antibody titres against herpes simplex, and one of these also had a rise in titre against the varicella-zoster antigen. In both patients, however, the acute pancreatitis had followed immediately upon an episode of excessive alcohol intake. These minor changes in titres are felt to be aetiologically insignificant. Even in those acute pancreatitis patients where known predisposing factors - for example, alcohol abuse, biliary diseasewere absent, no four-fold rises in antibody titre were found. Of the patients where only single serum samples were tested, one had a high titre of antibody to the psittacosis/LGV antigen, the significance of which was not clear. No other patient with acute or chronic pancreatic disease had viral antibody titres suggestive of recent infection.

The finding of a greater incidence of antibody titres $>1: 20$ against Coxsackie $B_{3}$ and $B_{4}$ viruses among patients with acute pancreatitis, irrespective of cause, compared with controls, requires explanation. The difference is unlikely to have arisen because of the particular sera used as controls, since these had been obtained from patients with suspected viral disease and might have been expected therefore to have shown increased viral antibody titres. This may explain the increased incidence of adenovirus antibodies in the control group. The control and pancreatitis sera were matched within one month for time of collection, and came from patients living in the same area of London, so that seasonal and geographical factors are unlikely to be of importance. The raised titres in the pancreatitis patients may have resulted from a selective anamnestic response brought about by the pancreatitis itself, irrespective of its aetiology. Alternatively, persistent low-grade infection with Coxsackie B viruses may perhaps be present in this group of patients. Again, it is possible that pancreatic antigens released by the inflammatory process share common determinants with 
Coxsackie antigens, thus giving rise to cross-reacting antibodies. Although no significant correlation was found between autoantibodies against acinar cells in fluorescent tests and raised Coxsackie antibody titres, it is quite possible that other cross-reacting antibodies are present.

These findings are similar to those in a study of insulin-dependent diabetics who showed a greater incidence of neutralizing antibody titres $>1: 20$ against Coxsackie $\mathbf{B}_{4}$ compared wtih matched controls (Gamble et al., 1969). One possible common explanation for these similar observations in diabetes and in pancreatitis might be a histocompatabilitylinked immune response as is known to occur in animals (Benacerraf and McDevitt, 1972). Further studies of the inter-relationships between viral antibodies, autoantibodies and HL-A antigens would be of interest.

We are indebted to the physicians and surgeons of St. Mary's Hospitals, W2 and W9, and The Middlesex, Central and West Middlesex Hospitals, who have allowed us to study patients under their care, and to Mrs. D. Irving, St. Mary's Hospital, for statistical advice. We thank the Central Public Health Laboratory, Colindale, for supplying viral antigens, Professor K. R. Dumbell for helpful discussions, and the technical staff of the Diagnostic Virology Department, St. Mary's Hospital, W2 for valued assistance.

\section{References}

Achord, J. L. (1968). Acute pancreatitis with infectious hepatitis. Journal of the American Medical Association, 205, 837-840.

Bank, S., and Marks, I. N. (1970). Hyperlipaemic pancreatitis and the pill. Postgraduate Medical Journal, 46, 576-578.

Benacerraf, B., and McDevitt, H. O. (1972). Histocompatibility-linked immune response genes. Science, 175, 273-279.

Bradstreet, C. M. P., and Taylor, C. E. D. (1962). Technique of complement-fixation test applicable to the diagnosis of virus diseases. Monthly Bulletin of the Ministry of Health and the Public Health Laboratory Service, 21, 96-104.

Bunnell, C. E., and Monif, G. R. G. (1972). Interstitial pancreatitis in the congenital rubella syndrome. Journal of Pediatrics, 80, 465-466.

Burch, G. E., Tsui, C. Y., and Harb, J. M. (1974). Pancreatitis of mice infected with encephalomyocarditis virus. Pathologia et Microbiologia, 40, 281-296.

Burch, G. E., Tsui, C. Y., Harb, J. M., and Colcolough, H. L. (1971). Pathologic findings in the pancreas of mice infected with Coxsackie virus B4. Archives of Internal Medicine, 128, 40-47.

Craighead, J. E. (1965). Necrosis of the pancreas, parotid and lachrymal glands associated with encephalomyocarditis virus infection. Nature, 207, 1268-1269.

Davidoff, F., Tishler, S., and Rosoff, C. (1973). Marked hyperlipidemia and pancreatitis associated with oral contraceptive therapy. New England Journal of Medicine, 289, 552-555.
Everett, E. D., Volpe, J. A., and Bergin, J. J. (1969). Pancreatitis in infectious mononucleosis. Southern Medical Journal, 62, 359-360.

Fechner, R. E., Smith, M. G., and Middelkamp, J. N. (1963). Coxsackie $B$ virus infection of the newborn. American Journal of Pathology, 42, 493-503.

Feldman, H. A. (1968). Removal by heparin- $\mathrm{MnCl}_{2}$ of nonspecific rubella hemagglutinin serum inhibitor. Proceedings of the Society for Experimental Biology and Medicine, 127, 570-573.

Gambill, E. E. (1973). Pancreatitis, p. 50. Mosby: St. Louis.

Gamble, D. R., Kinsley, M. L., Fitzgerald, M. G., Bolton, R., and Taylor, K. W. (1969). Viral antibodies in diabetes mellitus. British Medical Journal, 3, 627-630.

Gillespie, W. J. (1973). Viral hepatitis and acute pancreatitis. Journal of the Royal College of Surgeons of Edinburgh, 18, 120-122.

Ham, J. M., and Fitzpatrick, P. (1973). Acute pancreatitis in patients with acute hepatic failure. American Journal of Digestive Diseases, 18, 1079-1083.

Harrison, A. K., Bauer, S. P., and Murphy, F. A. (1972). Viral pancreatitis: ultrastructural pathological effects of Coxsackie virus B3 infection in newborn mouse pancreas. Experimental and Molecular Pathology, 17, 206-219.

Hirano, T., and Ruebner, B. H. (1968). Pancreatitis in mouse hepatitis virus $\left(\mathrm{MHV}_{3}\right)$ infection and its strain specificity. Federation Proceedings, 27, 664.

Jones, P. E., and Oelbaum, M. H. (1975). Frusemide-induced pancreatitis. British Medical Journal, 1, 133-134.

Joske, R. A. (1955). Aetiological factors in the pancreatitis syndrome. British Medical Journal, 2, 1477-1481.

Kibrick, S., and Benirschke, K. (1958). Severe generalized disease (encephalohepatomyocarditis) occurring in the newborn period and due to infection with Coxsackie virus, group B. Pediatrics, 22, 857-874.

Leinikki, P., Pantzar, P., and Tykkä, H. (1973). Antibody response in patients with acute pancreatitis to Mycoplasma pneumoniae. Scandinavian Journal of Gastroenterology, 8, 631-635.

Lendrum, R., and Walker, G. (1975). Serum antibodies in human pancreatic disease. Gut, 16, 365-371.

Lisney, A. A. (1943). Infective hepatitis in Leicestershire: a survey of 1,062 cases. Proceedings of the Royal Society of Medicine, 37, 165-170.

Mårdh, P-A., and Ursing B. (1974). The occurrence of acute pancreatitis in Mycoplasma pneumoniae infection. Scandinavian Journal of Infectious Diseases, 6, 167-171.

Minkowitz, S., and Berkovich, S. (1970). Hepatitis produced by Coxsackie virus B1 in adult mice. Archives of Pathology, 89, 427-433.

Murphy, A. M., and Simmul, R. (1964). Coxsackie B4 virus infections in New South Wales during 1962. Medical Journal of Australia, 2, 443-445.

Myhre, J. and Nesbitt, S. (1949). Pancreatitis in infectious mononucleosis. Journal of Laboratory and Clinical Medicine, 34, 1671-1675.

Nakao, T., Nitta, T., Miura, R., Ogata, K., Kume, T., Nobuta, K., and Hinuma, Y. (1964). Clinical and epidemiological studies on an outbreak of aseptic meningitis caused by Coxsackie B5 and A9 viruses in Aomori in 1961. Tohoku Journal of Experimental Medicine, 83, 94-102.

Pappenheimer, A. M., Kunz, L. J., and Richardson, S. (1951). Passage of Coxsackie virus (Connecticut-5 strain) in adult mice with production of pancreatic disease. Journal of Experimental Medicine, 94, 45-64.

Platt, H. (1956). A study of the pathological changes produced in young mice by the virus of foot-and-mouth disease. Journal of Pathology and Bacteriology, 72, 299-312.

Ross, M. E., Hayashi, K., and Notkins, A. L. (1974) 
Virus-induced pancreatic disease: alterations in concentration of glucose and amylase in blood. Journal of Infectious Diseases, 129, 669-676.

Stewart, G. L., Parkman, P. D., Hopps, H. E., Douglas, R. D., Hamilton, J. P., and Meyer, H. M. (1967). Rubellavirus hemagglutination-inhibition test. New England Journal of Medicine, 276, 554-557.

Trapnell, J. E., and Duncan, E. H. L. (1975). Patterns of incidence in acute pancreatitis. British Medical Journal, 2, 179-183.
Tsui, C. Y., Burch, G. E., and Harb, J. M. (1972). Pancreatitis in mice infected with Coxsackie virus B1. Archives of Pathology, 93, 379-389.

Ursing, B. (1973). Acute pancreatitis in Coxsackie B infection. British Medical Journal, 3, 524-525.

Wislocki, L. C. (1966). Acute pancreatitis in infectious mononucleosis. New England Journal of Medicine, 275, 322-323.

Wood, E. M., Snieszko, S. F., and Yasutake, W. T. (1955). Infectious pancreatic necrosis in brook trout. Archives of Pathology, 60, 26-28.

\section{The October 1975 Issue}

\section{THE OCTOBER 1975 ISSUE CONTAINS THE FOLLOWING PAPERS}

Stimulation of water and sodium secretion and inhibition of glucose absorption from the rat jejunum during intraarterial infusions of prostaglandins I. M. COUPAR AND IAN MCCOLL

Gastrin response to meals of different composition in normal subjects E. L. BLAIR, J. R. GREENWELL, E. R. GRUND, J. D. REED, AND D. J. SANDERS

The role of the antrum in determining the acid secretory response to meals of different consistency D. R. HUNT AND A. P. M. FORREST

The gastric response to a transpyloric duodenal tube GEORGE F. LONGSTRETH, JUAN-R. MALAGELADA, AND VAY L. W. GO

Is there an antral-body portal system in the stomach? T. V. TAYLOR AND BRUCE TORRANCE

Comparison of bowel function after ileorectal anastomosis for ulcerative colitis and colonic polyposis C. R. NEWTON AND W. N. W. BAKER

Polyposis in ulcerative colitis R. H. TEAGUE AND A. E. READ
The ultrastructure of hepatocytes in alpha-1-antitrypsin deficiency with the genotype $\mathrm{Pi}_{-}$- G. FELDMANN, J.-P. MARTIN, R. SESBOUE, C. ROPARTZ, R. PERELMAN, M. NATHANSON, P. SERINGE, AND J.-P. BENHAMOU

Serum transaminase levels after experimental paracetamol-induced hepatic necrosis M. F. DIXON, M. J. FULKER, B. E. WALKER, J. KELLEHER, AND M. S. LOSOWSKY

Large bowel myoelectrical activity in man $I$. TAYLOR, H. L. DUTHIE, R. SMALLWOOD, AND D. LINKENS

Progress report Large bowel cancer: causation and management M. B. MCILLMURRAY AND M. J. S. LANGMAN

The British Society of Gastroenterology

Notes and activities

Notes on books

Copies are still available and may be obtained from the PUBLISHING MANAGER, BRITISH MEDICAL ASSOCIATION, TAVISTOCK SQUARE, LONDON, WC1H 9JR, price $£ 2.00$ including, postage 